\title{
Death Receptors and Their Ligands in Inflammatory Disease and Cancer
}

\author{
Alessandro Annibaldi ${ }^{1}$ and Henning Walczak ${ }^{2,3,4}$ \\ ${ }^{1}$ Center for Molecular Medicine Cologne, University of Cologne, 50931 Cologne, Germany \\ ${ }^{2}$ Center for Biochemistry, University of Cologne, 50931 Cologne, Germany \\ ${ }^{3}$ Cologne Excellence Cluster on Cellular Stress Responses in Aging-Associated Diseases (CECAD), \\ University of Cologne, 50931 Cologne, Germany \\ ${ }^{4}$ Centre for Cell Death, Cancer, and Inflammation (CCCl), UCL Cancer Institute, University College, \\ London WC1E 6BT, United Kingdom \\ Correspondence: a.annibaldi@uni-koeln.de; h.walczak@uni-koeln.de; h.walczak@ucl.ac.uk
}

On binding to their cognate ligands, death receptors can initiate a cascade of events that can result in two distinct outcomes: gene expression and cell death. The study of three different death receptor-ligand systems, the tumor necrosis factor (TNF)-TNF receptor 1 (TNFR1), the CD95L-CD95, and the TNF-related apoptosis-inducing ligand (TRAIL)-TRAIL-R1/2 system, has drawn the attention of generations of scientists over the past 50 years. This scientific journey, as often happens in science, has been anything but a straight line to success and discoveries in this field were often made by serendipity, catching the scientists by surprise. However, as Louis Pasteur pointed out, luck prefers the prepared mind. It is therefore not surprising that the most impactful discovery of the field to date, the fact that TNF inhibition serves as an effective treatment for several inflammatory and autoimmune diseases, has been like this. Luckily, the scientists who made this discovery were prepared and, most importantly, determined to harness their discovery for therapeutic benefit. Today's research on these death receptor-ligand systems has led to the discovery of a causal link between cell death induced by a variety of these systems and inflammation. In this review, we explain why we predict that therapeutic exploitation of this discovery may profoundly impact the future treatment of inflammatory disease and cancer.

\section{SIGNALING BY DEATH RECEPTORS AND THEIR LIGANDS}

B efore we discuss the role of death receptor (DR)-ligand systems in inflammation-associated diseases and cancer, we will give an update on the current understanding of ligand-stimulated signaling by these receptors.
DRs are a class of cell surface-expressed type I transmembrane receptors that form part of the tumor necrosis factor (TNF) receptor superfamily (TNFRSF) (Walczak 2013). The defining characteristic of a DR is the presence of the socalled death domain (DD) within the cytoplasmic portion. This class of receptors includes TNF receptor 1 (TNFR1) (Loetscher et al. 1990; Schall

Editors: Kim Newton, James M. Murphy, and Edward A. Miao

Additional Perspectives on Cell Survival and Cell Death available at www.cshperspectives.org

Copyright $(C) 2020$ Cold Spring Harbor Laboratory Press; all rights reserved

Advanced Online Article. Cite this article as Cold Spring Harb Perspect Biol doi: 10.1101/cshperspect.a036384 
et al. 1990), CD95 (Fas/APO-1) (Oehm et al. 1992; Itoh and Nagata 1993), TNF-related apoptosis-inducing ligand (TRAIL)-R1 (DR4) (Pan et al. 1997b), TRAIL-R2 (DR5, APO-2/TRICK/ DR5/KILLER) (Pan et al. 1997a; Screaton et al. 1997a; Sheridan et al. 1997; Walczak et al. 1997; Wu et al. 1997), and DR3 (TRAMP) (Chinnaiyan et al. 1996). On cross-linking by their respective cognate ligands, DRs have the capacity to induce the death of the cell on which they are expressed. However, despite the concept implicit in their name, cell death is by no means the only possible functional signaling outcome of DR stimulation and, at least for some of them, it is also not the default outcome (Fig. 1).

TNF binds to TNFR1 and TNFR2. However, only TNFR1 contains a DD and therefore forms part of the DR subfamily (Medler and Wajant 2019; Wajant and Siegmund 2019). The TNFR1 signaling pathway is the best studied of all DR signaling pathways and we will begin by providing an in-depth explanation of this pathway (Fig. 1). TNF binding to TNFR1 triggers receptor trimerization and the formation of the TNFR1 signaling complex (TNFR1-SC; also referred to as TNF-RSC or complex I of TNFR1 signaling) (Micheau and Tschopp 2003; Annibaldi and Meier 2018). TNFR1-SC formation is initiated by DD-dependent recruitment of TRADD and RIPK1 to the receptor (Kelliher et al. 1998). Subsequent binding of the adaptor TRAF2 to TRADD, in turn, mediates recruitment of the E3 ligases cIAP1 and cIAP2 (Rothe et al. 1995; Hsu et al. 1996; Micheau and Tschopp 2003; Ermolaeva et al. 2008). These two cIAPs place ubiquitin chains of various topologies (i.e., K11, K48, and K63 linkages) on RIPK1 and other components of the TNFR1-SC (Dynek et al. 2010; Annibaldi et al. 2018). These ubiquitin chains serve as scaffolds to recruit the linear ubiquitin chain assembly complex (LUBAC) (Haas et al. 2009). LUBAC is a tripartite E3 ligase complex that consists of the central catalytic component HOIP (also called RNF31), HOIL1 (also called RBCK1), and SHARPIN (also called SIPL1) (Gerlach et al. 2011; Ikeda et al. 2011). LUBAC conjugates linear ubiquitin chains (also referred to as Met1 or M1 chains) to several TNFR1-SC components, including
RIPK1, NEMO, TRADD, and TNFR1 itself (Gerlach et al. 2011; Draber et al. 2015). To date, LUBAC is the only E3 ligase known to generate linear ubiquitin chains de novo (Haas et al. 2009; Gerlach et al. 2011). This activity is crucial in the context of various signaling pathways, including in TNFR1 signaling (Zinngrebe et al. 2014; Peltzer et al. 2016). The ubiquitin chains generated by cIAP $1 / 2$ and LUBAC recruit different kinase-containing subcomplexes: the TAK1/TAB2/TAB3 (Ori et al. 2013), NEMO/ IKK $\alpha / \mathrm{IKK} \beta$ (Rahighi et al. 2009), NEMO/ TANK/TBK1/IKK $\varepsilon$, and NEMO/NAP1/TBK1 complexes (Lafont et al. 2018). Although the TAK1 and IKK $\alpha / \beta$ complexes are necessary for gene activation via MAPKs and NF- $\kappa B$, the different NEMO-containing kinase complexes are required to phosphorylate RIPK1 in TNFR1-SC at distinct sites, and this inhibits TNF-induced cell death (Dondelinger et al. 2015, 2019; Jaco et al. 2017; Lafont et al. 2018). TNF-induced gene expression leads to the production of cytokines and prosurvival proteins, which are required to mount an innate immune response.

TNF signaling is tightly regulated by a series of checkpoints that are dependent on ubiquitination, phosphorylation, gene expression, and protein cleavage events (Ting and Bertrand 2016; Annibaldi and Meier 2018). Circumstances that compromise these checkpoints often result in the formation of a secondary, cytoplasmic complex, referred to as complex II (Micheau and Tschopp 2003). The core components of complex II are RIPK1, FADD, caspase-8, cFLIP and, if expressed in the cell, RIPK3 (Wang et al. 2008; Zhang et al. 2009; Feoktistova et al. 2011; Tenev et al. 2011). The signals that induce cell death by apoptosis and necroptosis emanate from this complex. Apoptosis is initiated by RIPK1/FADD-mediated activation of caspase8 , which in turn activates the executioner caspase- 3 and caspase-7. Necroptosis is mediated by the RIPK1/RIPK3/MLKL axis on genetic deletion or pharmacological inhibition of caspase8. It requires the kinase activities of both RIPK1 and RIPK3 (Pasparakis and Vandenabeele 2015; Peltzer and Walczak 2019). Both ubiquitination and phosphorylation of RIPK1 are required to 


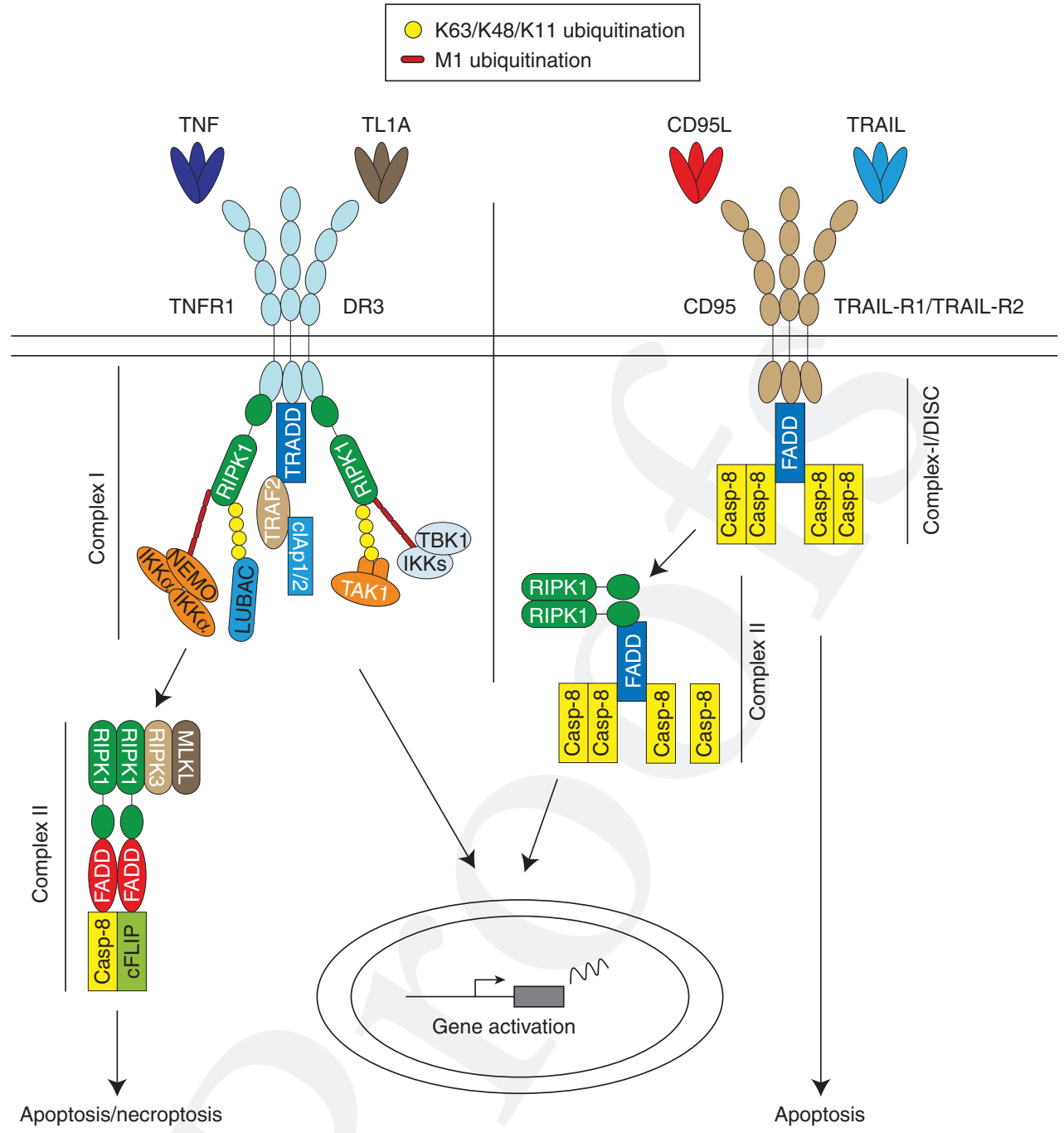

Figure 1. Tumor necrosis factor (TNF) receptor 1 (TNFR1)/DR3 and CD95/TNF-related apoptosis-inducing ligand (TRAIL)-R1/2 signaling pathways. Binding of TNF and TL1A to TNR-R1 and DR3, respectively, and CD95L and TRAIL to CD95 and TRAIL-R1/2, respectively, induces formation of a membrane-bound complex referred to as complex I or death-inducing signaling complex (DISC) in the case of CD95 and TRAIL-R1/2. TNFR1- and DR3-mediated complex I triggers gene expression via NF- $\mathrm{BB}$ and MAPKs, whereas the DISC has the potential to induce cell death by apoptosis or necroptosis. These two primary complexes dissociate from the respective receptors and incorporate additional proteins to form a secondary cytosolic complex called complex II. In the case of TNFR1 and TL1A, this complex induces caspase-8-mediated apoptosis or RIPK3/MLKL-mediated necroptosis. CD95 and TRAIL-R1/2 complex II triggers gene activation via NF- $\kappa \mathrm{B}$ and MAPKs.

prevent it from leaving TNFR1-SC and nucleating a death-promoting complex II.

Until a few years ago, the prevailing concept was that abnormally high TNF-induced gene expression was the (only) cause of TNF-induced inflammation. TNF-induced cell death was re- garded as less relevant, perhaps even irrelevant, to the chronic inflammatory and autoimmune disorders known to be driven by TNF. However, this view has dramatically changed in recent years as explained in the next section of this review. 
DR3 and its ligand TL1A appear to signal in essentially the same way as TNF and TNFR1 (Fig. 1). Expression of TL1A and DR3 is mainly restricted to immune cells (Marsters et al. 1996; Screaton et al. 1997b). This system has been reviewed thoroughly elsewhere (Richard et al. 2015), but suffice to state that little is known regarding the relative contribution of TL1A-mediated gene activation versus TL1A-induced cell death to inflammation. This topic likely represents an interesting field for future study of TL1A and DR3.

The TRAIL and CD95L (FasL/APO-1L) signaling pathways share many components with the TNF pathways. Both ligands trigger the formation of membrane-bound and cytoplasmic complexes, but their roles are reversed in comparison to TNFR1 complexes (Walczak 2013). Although TNFR1-SC mediates gene activation and TNFR1 complex II triggers cell death, TRAIL and CD95L assemble a primary deathinducing signaling complex (DISC). Secondly, cytoplasmic complexes activate gene expression. TRAIL binding to TRAIL-R1 and/or TRAIL-R2 (or CD95L binding to CD95) oligomerizes the receptor and the intracellular DDs adopt a conformation that enables FADD recruitment (Chinnaiyan et al. 1995; Shirley et al. 2011). It has been shown that receptor hexamerization is the optimal assembly for cell death induction by these two death ligands, which explains why hexameric receptor agonists are potent inducers of cell death by TRAIL-R1/2 and CD95 (Holler et al. 2003; Valley et al. 2012). FADD in turn recruits caspase- 8 and caspase-10 via death effector domain (DED) interactions. Caspase-8 undergoes ubiquitination by cullin-3, increasing its clustering and activation (Jin et al. 2009). Besides inducing cell death, TRAIL and CD95L can also activate NF- $\mathrm{BB}$ and MAPKs through a secondary complex, complex II, whose core components are RIPK1, NEMO, TRAF2, caspase-8, and FADD (von Karstedt et al. 2017). Recently, it was shown that the TRAIL DISC can also elicit gene activation through NF- $\mathrm{KB}$ (Hartwig et al. 2017; Henry and Martin 2017) using LUBAC (Lafont et al. 2017). Interestingly, whereas RIPK1 is only important for TNFinduced gene activation in some instances
(Wong et al. 2010), RIPK1 is required for TRAIL-induced gene expression (Hartwig et al. 2017; Henry and Martin 2017).

\section{DEATH RECEPTORS AND THEIR LIGANDS IN INFLAMMATORY DISEASES}

\section{TNF in Chronic Inflammation and Autoimmunity}

TNF is a potent inflammatory cytokine that coordinates immune responses following tissue damage or pathogen infection. Initially, however, TNF was thought to induce necrosis in tumor cells, a concept that obviously inspired the naming of this cytokine. Although the purified activity then referred to as TNF did induce tumor necrosis, most strikingly in certain sarcomas (Carswell et al. 1975), this proved the exception rather than rule after TNF was cloned. Most cell types exposed to TNF induce the expression of a plethora of proinflammatory cytokines and chemokines, rather than dying (Beutler 1999). It is therefore not surprising that the study of TNFinduced cell death became the wallflower of cell death research for many years. The pathway appeared obscure at a time when the field was focused on deciphering the canonical apoptosis program. A few scientists kept studying this form of cell death, inspired by the fact that it could clearly be triggered, and thus occurred in a programmed manner (Vanden Berghe et al. 2004; Vandenabeele et al. 2006).

The concept of TNF being a potent proinflammatory factor became entrenched in the scientific community in the late 1980s and early 1990 s, which is when scientists were trying to understand how inhibition of cytokines could be used in the treatment of inflammatory diseases. According to one school of thought, therapeutic intervention in such multifactorial diseases would be impossible because of redundancy among the cytokines instigating inflammation. However, the optimists' view was that an apical cytokine triggered the inflammatory cascade involving a plethora of cytokines. The first indication that TNF might be that apical cytokine, and consequently a worthy therapeutic target, came from cultures of dissociated 
rheumatoid synovial membranes obtained from rheumatoid arthritis (RA) patients. In this study, blocking TNF prevented the production of many inflammatory cytokines, including interleukin (IL)-1, IL-6, and IL-8, which had also been considered candidate apical cytokines (Brennan et al. 1989). Further support for this concept came from studies showing that TNF and TNFR1 are up-regulated in inflamed tissues of RA patients (Chu et al. 1991; Deleuran et al. 1992). The ultimate proof for this groundbreaking discovery came when TNF inhibitors afforded therapeutic benefit to patients suffering from RA (Elliott et al. 1993; Moreland et al. 1999; Weinblatt et al. 1999; Bathon et al. 2000; Lovell et al. 2000). Shortly after the approval of the first TNF inhibitor (enbrel/etanercept) in 1997, other biotherapeutic inhibitors of TNF were approved for the treatment of various chronic inflammatory and autoimmune diseases. Besides RA and other arthritides, the most prominent indications were psoriasis, and the two most prevalent forms of inflammatory bowel disease (IBD) in Crohn's disease (CD) and ulcerative colitis (UC) (Monaco et al. 2015). The therapeutic success of TNF inhibition has been tremendous, indeed unprecedented in the treatment of chronic inflammatory and autoimmune diseases (Brenner et al. 2015; Kalliolias and Ivashkiv 2016). Since their introduction in 1997, TNF blockers have helped millions of patients live a life in which their disease is controlled, albeit not cured.

\section{Death Ligands beyond TNF in Inflammation and Autoimmunity}

Unfortunately, anti-TNF therapy does not help all patients suffering from one of the aforementioned disorders. In about half the patients suffering from RA, long-lasting benefits can be achieved through the inhibition of TNF, whereas the other half of RA patients do not benefit from this treatment. The same is true for $\sim 35 \%$ of patients with psoriasis and between $20 \%$ and $40 \%$ of patients suffering from the different forms of IBD (Cho and Feldman 2015; Lopetuso et al. 2017). TNF inhibition also provided no therapeutic benefit in patients with the autoim- mune disorders multiple sclerosis (MS) and amyotropic lateral sclerosis (ALS), despite a clear up-regulation of the TNF system in these disorders (Lenercept Multiple Sclerosis Study Group 1999). One interpretation of these failures is that TNF is not the apical regulator of inflammation in nonresponding patients, and inflammation is instead instigated by different means.

This view was challenged by the realization that TNF can mediate inflammation not only by activating gene expression, but also by inducing aberrant cell death (Fig. 2). For example, mutation of the Sharpin gene in mice causes chronic proliferative dermatitis (cpdm) (Seymour et al. 2007). In cells of these mice, TNFinduced gene activation is attenuated, whereas the induction of cell death is increased (Gerlach et al. 2011). At the time, this result provided a conundrum: how did the mouse develop an inflammatory disease if proinflammatory gene expression in response to TNF was compromised? One could argue that an inflammatory mediator other than TNF drove inflammation. However, gene activation by other inflammatory mediators, including CD40L, was also compromised in Sharpin-deficient cells (Gerlach et al. 2011). Given that TNF-induced cell death was aberrantly increased, we reasoned that genetic ablation of $\operatorname{Tnf}$ could address two questions: (1) does aberrant cell death cause the inflammatory syndrome in cpdm mice, and (2) is TNF the intrinsic agent provocateur of this cell death? Indeed, genetic deletion of Tnf, even heterozygous deletion of Tnf, prevented both cell death in the skin and inflammatory disease in $c p d m$ mice. Therefore, we concluded that TNF-induced cell death caused inflammation in these mice (Gerlach et al. 2011). This discovery was genetically confirmed when it was shown that codeletion of Casp8 and Mlkl, or Fadd and Ripk3, also prevented cell death in the skin and inflammatory disease in $c p d m$ mice (Kumari et al. 2014; Rickard et al. 2014; Peltzer et al. 2018). Other genetic mouse models of inflammatory disease have also been shown to be driven by excessive cell death (Welz et al. 2011; Dannappel et al. 2014; Kumari et al. 2014; Vlantis et al. 2016). Important- 


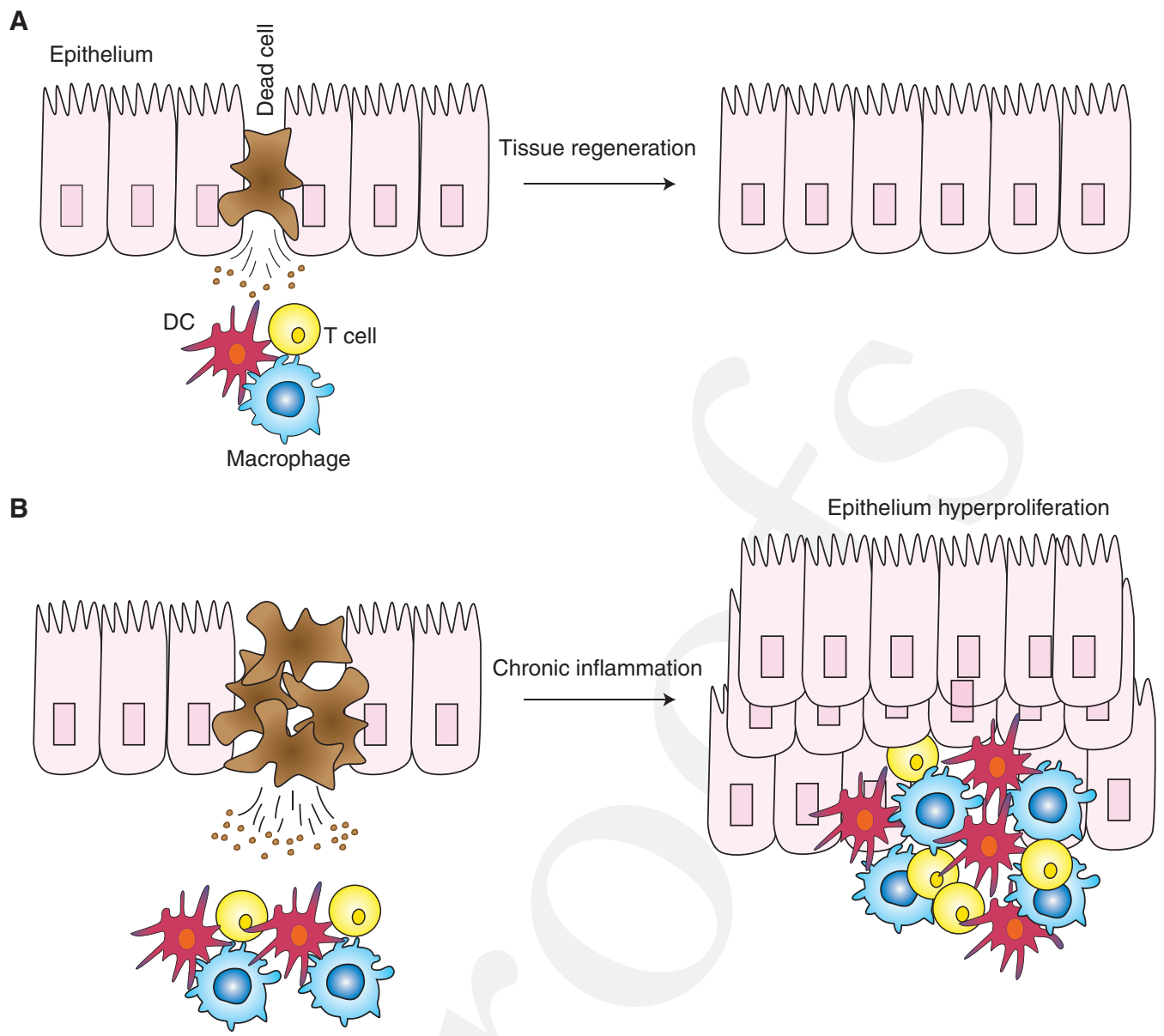

Figure 2. Aberrant cell death in chronic inflammation. (A) Cell death is important for the repair and regeneration programs of different types of tissues, such as the epithelium of the skin and the intestine. Dying cells release factors that trigger the activation of an inflammatory program, whose ultimate purpose is to restore tissue integrity. ( $B$ ) Deregulated cell death determines the persistence of tissue repair programs, which in turn leads to chronic inflammation, epithelial cell hyperproliferation, and, ultimately, to an autoinflammatory or autoimmune disorder. (DC) Dendritic cell.

ly, several of these genetic alterations have also been found in humans, although these alterations appear to be rare. These individuals often suffer from a combination of autoinflammation and immunodeficiency (Fusco et al. 2008; Cuchet-Lourenco et al. 2018; Oda et al. 2019).

A further advance in the understanding of the etiology of inflammatory diseases came when it was shown that pharmacologic or genetic inhibition of RIPK1 prevented dermatitis in $c p d m$ mice (Berger et al. 2014). Thus, by blocking the kinase activity of RIPK1, TNF-induced cell death and skin inflammation was prevented. These findings raised the possibility that inhibition of RIPK1 might suffice to block aberrant TNF-induced cell death and consequent inflammation. If this were the case, then TNF blockade could potentially be replaced by inhibition of RIPK1. Additional preclinical studies showed that inhibition of RIPK1 could also ameliorate TNF-induced septic shock, anticollagen antibody-induced arthritis, and inflammation and tissue injury caused by A20 deficiency, but it provided no benefit in other models, such as 
chemically induced pancreatitis (Newton et al. 2016; Patel et al. 2020).

Given that several biotherapeutic inhibitors of TNF figure in the list of the world's top 10 best-selling drugs, it is not surprising that this concept garnered the attention of the biotech and pharmaceutical industries. Many companies are currently bringing RIPK1 kinase inhibitors into clinic testing. However, the first phase II clinical trials, which were performed in RA, psoriasis, and IBD patients, did not appear to reveal a benefit and the inhibitor has recently "moved back to research" (see gsk.com/media/ 5745/q3-2019-results-slides.pdf). Could it be that the notion of inflammatory disease being caused by aberrant TNF-induced RIPK1-kinase-dependent cell death is just too simple? Recent evidence suggests this might indeed be the case. For example, lethal dermatitis induced by keratinocyte-specific genetic deletion of Hoip or Hoil-1 $\left(\right.$ Hoip $^{E-K O}$ or Hoil-1 $\left.{ }^{E-K O}\right)$ is considerably delayed by codeletion of Tnfrl, whereas inhibition of RIPK1 only delays lethal dermatitis by a few days (Taraborrelli et al. 2018). Intriguingly, however, when Hoip ${ }^{E-K O} ; \operatorname{Tnfr} 1^{-/-}$or Hoil-1 ${ }^{E-K O} ;$ Tnfr $^{-/-}$mice are given an RIPK1 kinase inhibitor, lethal dermatitis is prevented (Taraborrelli et al. 2018). Thus, at least in this genetic model, TNFR1 ablation and RIPK1 kinase inhibition are synergistic at inhibiting cell death and consequent inflammation. Nevertheless, this discovery suggests that combining a TNF inhibitor and an RIPK1-specific inhibitor might benefit certain autoimmune or autoinflammatory disease patients. For patients with rare germline mutations impacting LUBAC components, this combination may represent an alternative treatment strategy if their current therapies do not work or if they develop resistance to them. An outstanding question, however, is what drives RIPK1-dependent cell death and disease when the TNF/TNFR1 system is absent.

The idea that TNF superfamily (TNFSF) cytokines beyond TNF itself could act individually or in a concerted manner to promote inflammation has been proposed, albeit with cell-deathindependent mechanisms and disease etiologies in mind (Croft and Siegel 2017). At present, several TNFSF proteins are under evaluation in preclinical and clinical studies as potential targets in various rheumatic and chronic inflammatory diseases. Especially noteworthy in the context of this review are TRAIL and CD95L. The primary signaling output of these two TNFSF members is cell death, which is in contrast to that of TNF and TL1A (Fig. 1). Nevertheless, as described earlier, both the TRAILTRAIL-R1/R2 and CD95L-CD95 systems can induce gene activation (Hartwig et al. 2017; Henry and Martin 2017). The CD95L-CD95 system drives activation-induced T-cell death, which is instrumental in immune homeostasis (Alderson et al. 1995; Brunner et al. 1995; Dhein et al. 1995; Ju et al. 1995). Indeed, mutations in CD95 cause the accumulation of aberrant $\mathrm{T}$ cells, which ultimately results in autoimmunity (Watanabe-Fukunaga et al. 1992). The TRAIL-TRAIL-R system has mainly been characterized for its ability to selectively kill cancerous, but not essential normal cells. In addition to being expressed in cancer cells, TRAIL-R1 and TRAIL-R2 are also expressed on different subpopulations of $\mathrm{T}$ cells, whose apoptosis they can promote (Roberts et al. 2003; Zhang et al. 2003). Hence, the immunological "day job" of the CD95 and TRAIL systems appears to be the proper termination of an immune response and the prevention of autoimmunity. Indeed, the killing function of CD95 and TRAIL-R1/ $\mathrm{R} 2$ in activated or autoreactive $\mathrm{T}$ cells has led to the idea that autoreactive $\mathrm{T}$ cells might be eliminated in the context of autoimmunity using CD95L, TRAIL, or other DR agonists. The severe hepatotoxicity of CD95 agonists (Ogasawara et al. 1993) excludes their use, but TRAIL and other agonists of the TRAIL DRs may yet be an option, although this awaits therapeutic validation in patients.

Given that caspase-8-dependent cell death causes lethal inflammation in Hoip ${ }^{E-K O}$ and Hoil-1 ${ }^{E-K O}$ mice, as well as in Hoil- $1^{E-K O}$; $\mathrm{Tnfr}^{-/-}$and Hoip ${ }^{-\mathrm{KO}_{0}} ; \mathrm{Tnfr}^{-/-}$mice, the role of other DRs in inflammation must be considered (Taraborrelli et al. 2018). Indeed, cells deficient for HOIL-1 or HOIP are more sensitive to killing by TNF, TRAIL, or CD95L. Although neither constitutive deletion of Trail-r $r$ nor ker- 
atinocyte-specific deletion of the DD of CD95 ameliorated dermatitis in Hoil-1 ${ }^{E-K O} ;$ Tnfr 1 mice, eliminating both CD95 and TRAIL-R signaling significantly ameliorated dermatitis (Taraborrelli et al. 2018). Hence, cell death driven by CD95L and TRAIL also contributes to inflammation. The therapeutic potential this discovery may unleash is tremendous because it suggests that the prevention of disease-causing inflammation may require the simultaneous neutralization of cell death induction by multiple DR-ligand systems. Thus, for patients with a cell death-dependent disease etiology, blocking TNF may not be sufficient to achieve a lasting therapeutic benefit, whereas blocking TNF and these additional death ligands or their cell death-inducing signaling pathways, may well afford such benefit.

In summary, during the past decade we learned that (1) TNF-driven inflammatory and autoimmune disorders can also stem from TNFinduced cell death and not only from TNFinduced gene activation; (2) failure of TNF inhibitors to provide therapeutic benefit in all patients with inflammation-associated disease does not necessarily mean that TNF is not a valuable target in nonresponders; it might simply mean that blocking TNF is not sufficient and other death ligands-or their downstream effectors-have to be blocked in addition; and (3) these other death ligands can be TRAIL and CD95L, and the downstream effector essential for mediating cell death by them and not TNF could be the kinase activity of RIPK1. This last point leaves us with an intriguing biochemical question because, if anything, TNF-induced cell death would have been expected to require RIPK1 activity but not cell death induced by TRAIL and CD95L. This unexpected result leaves us with the realization that there is more plasticity between cell death pathways triggered by the different DRs than previously thought. Extending this concept, two recent studies showed that when the proteolytic activity of caspase- 8 is genetically ablated and necroptosis is inhibited, the system is rewired to activate yet a third modality of programmed cell death, caspase-1-dependent pyroptosis (Fritsch et al. 2019; Newton et al. 2019). This discovery expo- ses a previously unappreciated plasticity between the three major programmed cell death pathways. This rewiring likely represents an evolutionary necessity to survive the challenge of infection. The other, pathological side of the coin is something we are only beginning to unearth. It may have a major impact on our understanding of neuroinflammatory and neurodegenerative diseases (Ising et al. 2019), possibly guiding how we treat these diseases effectively in the future.

In conclusion, combining a TNF inhibitor with an RIPK1 kinase inhibitor or with inhibitors of CD95L, TRAIL, and/or other death ligands, might extend the reach of TNF-inhibitory therapies to patients who currently do not benefit from them. For example, patients with a disorder in which TNF inhibitors provide therapeutic benefit in many, but not all patients, such as RA, IBD (CD and UC), or psoriasis. However, equally, or perhaps even more, excitingly, this concept could extend to chronic inflammatory, autoimmune, and neuroinflammatory disorders in which TNF inhibition so far failed. Only future clinical trials testing the therapeutic concepts summarized here will reveal whether the insights gained from studying mouse models are also relevant to human patients.

\section{DEATH RECEPTORS AND THEIR LIGANDS IN CANCER}

\section{The TNF System in Cancer}

TNF owes its name to the fact that it was identified as the agent responsible for the tumornecrotizing activity of "Coley's toxins." Discovered and used at the end of the 19th century by William Coley in New York (Coley 1893), Coley's toxins consisted of a mixture of bacterial lysate products. It induced regressions of certain tumors, especially sarcomas (Nauts et al. 1946). However, enthusiasm for the identification of a soluble factor that could revolutionize cancer treatment did not persist in an era when the discoveries of chemo- and radiotherapy dominated cancer research and therapy. Nevertheless, scientists kept chasing this ominous activity 
and TNF was cloned with the advent of modern biochemical and genetic techniques (Gray et al. 1984; Pennica et al. 1984; Marmenout et al. 1985). The promise held by TNF for cancer treatment proved short-lived because systemic treatment with TNF caused a lethal inflammatory shock syndrome with massive cytokine induction (Tracey et al. 1988). For a long time, this was thought to be the result of increased TNFinduced gene expression rather than cell death (Balkwill 2009). Intriguingly, however, the cytokine storm responsible for TNF-induced shock was recently shown to indeed be a consequence of TNF-induced cell death (Newton et al. 2016). Today, TNF is exploited to treat cancer locally by isolated limb perfusion (ILP). In ILP, TNF is used in combination with chemotherapy (melphalan) for the treatment of locally advanced extremity soft tissue sarcoma (STS) (Neuwirth et al. 2017). In this case, the toxicity linked to systemic administration of TNF is circumvented by local treatment. At present, it is not entirely clear why some types of cancer, especially sarcomas, are susceptible to TNF, whereas the vast majority of cancers are not. TNF killing of tumor endothelial cells is likely involved in the observed tumor necrosis (Robaye et al. 1991).

Further discouraging the use of TNF as a cancer drug, a study published in 1999 showed that $\mathrm{Tnf}^{-{ }^{-}-}$mice challenged with the skin carcinogen DMBA and the tumor promoter TPA developed fewer tumors than wild-type mice (Moore et al. 1999). TNF also promotes the growth of syngeneic and carcinogen-induced tumors of the skin, pancreas, colon, and ovary (Suganuma et al. 1999; Kulbe et al. 2007; Zins et al. 2007; Egberts et al. 2008). These findings, together with evidence indicating that TNF is produced by both malignant cells and cells in the tumor microenvironment, suggest that TNF is a crucial, if not the central, regulator of cancerrelated inflammation (Mantovani et al. 2008; Balkwill and Mantovani 2012). Mechanistically, we now know that cancer cells promote a proinflammatory microenvironment that supports tumor cell survival and proliferation, angiogenesis, and metastasis, although dampening adaptive antitumor immune responses. The ability of cancer cells to promote such an inflammatory microenvironment is often mediated by the production of TNF. Collectively, these discoveries led to a paradigm shift with TNF being regarded as an endogenous tumor-promoting agent. Consequently, inhibition of TNF started to be considered in cancer therapy.

Our knowledge of the role of TNF in inflammation-related disorders might give us clues on how to best harness the biology of TNF in cancer therapy. As explained in the previous section, TNF-dependent autoimmune and inflammatory disease can be caused by aberrant TNFinduced cell death. Given the abundance of TNF in the microenvironment of many different cancers, the question arises as to whether we can rewire TNF signaling from its prosurvival and proliferative function into a cell death-inducing function. In other words, can we harness endogenous TNF in the microenvironment and use it to kill cancer cells? Several reports indicate this might indeed be possible. In these studies, some of the checkpoints that prevent TNF-induced cell death were manipulated for TNF to trigger cell death. For example, SMAC mimetics, which degrade cIAP1/2 and promote TNFR1 complex II formation, rendered cancer cells susceptible to TNF-induced cell death (Beug et al. 2014, 2017; Lalaoui et al. 2016). Pan-caspase inhibitors, like zVAD or emricasan, can also convert the TNF-induced signal in cancer cells into a necroptosis-inducing one (Brumatti et al. 2016). Intriguingly, cell death induced by TNF, especially necroptosis, appears to be highly immunogenic, facilitating tumor immunity. A recent study reported that lowering the threshold of TNF cytotoxicity increases the efficacy of cancer immunotherapy (Vredevoogd et al. 2019). Thus, if we could manipulate TNF signaling in cancer cells to trigger an immunogenic cell death, we might kill a fraction of the cells directly and evoke an antitumor immune response to target the escapees.

In summary, more than a century of biomedical research on TNF has been highly stimulating from a scientific perspective. Realization of the extraordinary potential of TNF inhibition in the treatment of autoimmune and chronic inflammatory diseases represents a striking advance of modern medicine. Future opportuni- 
ties related to its role in cancer-related inflammation await further preclinical research followed by clinical validation. Efforts focused on harnessing endogenous TNF in the tumor microenvironment and rendering it capable of killing cancer cells in a manner that stimulates antitumor immunity represents a fascinating new challenge. Clearly, TNF's exciting journey in tumor biology and immunology is far from over.

\section{The CD95 and TRAIL Systems in Cancer}

Coincident with hope fading for TNF as a viable cancer therapeutic, two antibodies, anti-APO-1 and anti-Fas, drew attention owing to their ability to directly kill cancer cells (Trauth et al. 1989; Yonehara et al. 1989). Their targets, Fas and APO-1, were found to belong to the TNFRSF (Itoh et al. 1991; Oehm et al. 1992). Disappointingly, however, both antibody and ligandderived CD95 agonists were highly toxic, causing massive hepatocyte death and fulminant hepatitis (Ogasawara et al. 1993).

Subsequently, the CD95L-CD95 system was shown to stimulate cancer cell proliferation, migration, and invasion (Owen-Schaub et al. 1993; Barnhart et al. 2004; Chen et al. 2010), including in glioblastoma (Kleber et al. 2008). Subsequent clinical testing of CD95-Fc (APG101/asunercept), a CD95L antagonist, showed that glioblastoma patients treated with this inhibitor plus radiotherapy benefited when compared with radiotherapy alone (Wick et al. 2014). Thus, based on our current understanding of the cancer biology of the CD95L-CD95 system, its inhibition rather than activation appears to provide benefit for cancer patients.

Soon after it was realized that CD95 agonists, like TNF, would not be a "magic bullet" for killing cancer cells, a new member of the TNFSF was identified. It most resembled CD95L, which was also known as FasL or APO-1L. Given that it could induce apoptosis similar to FasL, this new TNFSF member was named TRAIL or Apo2L (Wiley et al. 1995; Pitti et al. 1996). Importantly, TRAIL selectively killed cancer cells, without killing any essential normal cells, a unique combination of characteristics, which holds true both in vitro and in vivo (Walczak et al. 1997).
This finding provided the scientific basis for developing TRAIL-receptor agonists (TRAs) as novel cancer therapeutics. However, TRAIL-R1and TRAIL-R2-specific antibodies as well as a first recombinant form of TRAIL showed very limited anticancer activity in patients in clinical trials. As recently thoroughly reviewed elsewhere (von Karstedt et al. 2017), various strategies are currently underway to overcome the two issues which, together, are likely responsible for the failure of these first-generation TRAs, that is, (1) poor agonistic activity, and (2) resistance of most primary cancers to TRAIL-induced apoptosis.

Additionally, however, it recently emerged that the TRAIL-TRAIL-R system can be "hijacked" by certain cancers. Rather than killing cancer cells, recombinant TRAIL was found to act in a tumor-supportive manner (Trauzold et al. 2006), particularly in KRAS-mutated cancers (Hoogwater et al. 2010). It was then realized that endogenous TRAIL can be recruited by KRAS-mutated cancers to act in this manner. The mechanism whereby this is achieved is two-pronged: (1) by enhancing tumor cell proliferation, invasion, and metastasis in a TRAILR2 DD- and FADD-independent manner (von Karstedt et al. 2015), and (2) by creating a TRAIL-R2 DD- and FADD-dependent cytokine-rich micromilieu in which monocytes are polarized to become myeloid-derived suppressor cells (MDSCs) or alternatively activated (M2) macrophages (Fig. 3; Hartwig et al. 2017). Interestingly, the latter mechanism not only supports tumor growth, it also acts via immunosuppression. Therefore, TRAIL may represent a previously unrecognized immune checkpoint whose inhibition may unleash tumor immunity. It is interesting to note that TRAIL, albeit mostly in non-cancer-related contexts, has been shown to inhibit T helper type 1 (Th1) cells (Ikeda et al. 2010), promote regulatory $\mathrm{T}$ cells (Pillai et al. 2011), and suppress T-cell activation and proliferation by interfering with proximal $\mathrm{T}$-cell receptor (TCR) signaling (Lehnert et al. 2014). It can also kill immature dendritic cells (Leverkus et al. 2000). Thus, TRAIL inhibition may act via tumor-cell-centered suppressive as well as immunity-enabling antitumor effects. 

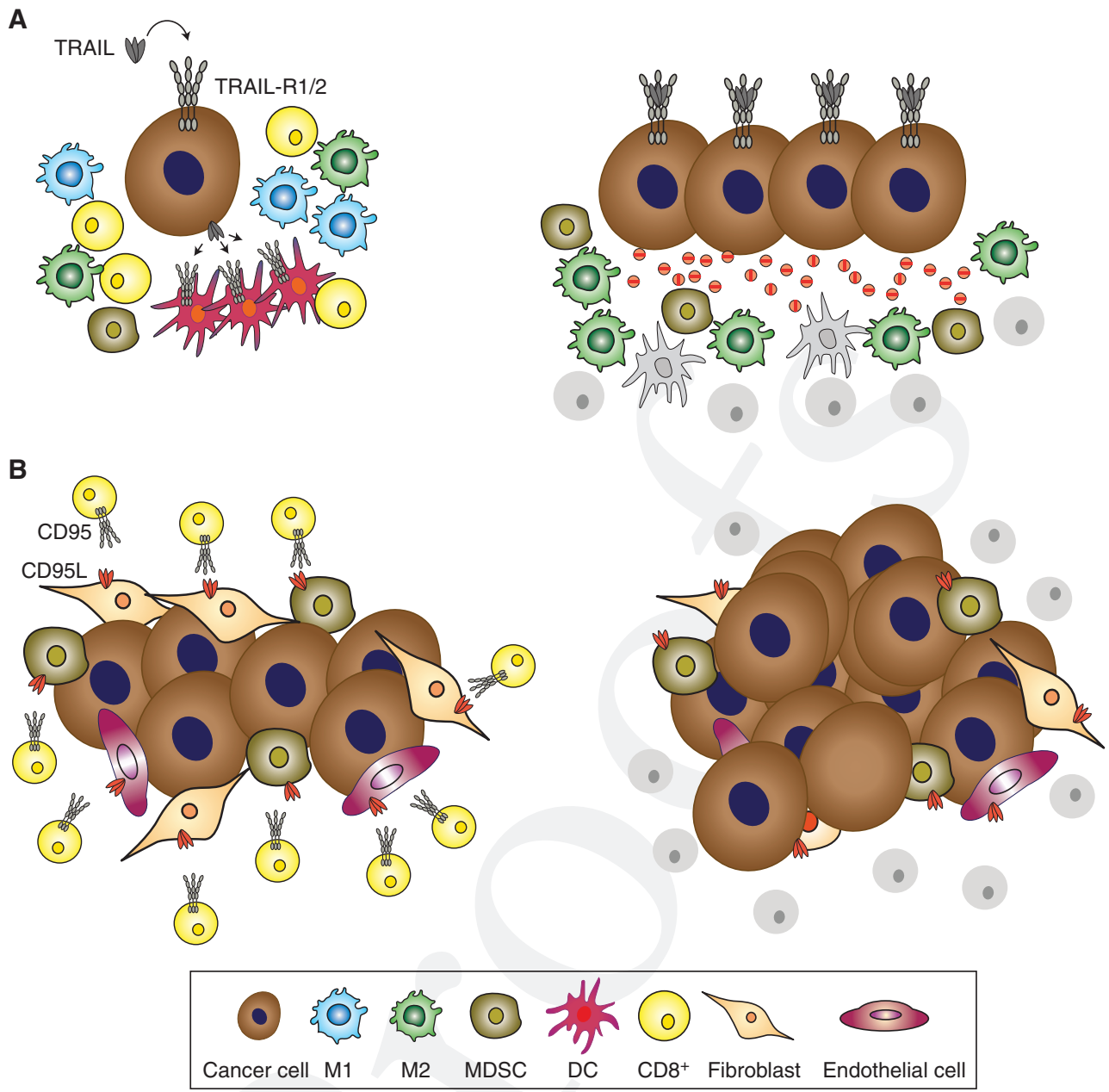

Figure 3. Mechanisms of death receptor (DR)-mediated immunosuppression in cancer. $(A)$ The TNF-related apoptosis-inducing ligand (TRAIL)/TRAIL-R1/2 system contributes to immunosuppression via distinct mechanisms. The activation of TRAIL-R1/2 expressed by cancer cells induces the secretion of cytokines that polarize monocytes into myeloid-derived suppressor cells (MDSCs) and alternatively activated (M2) macrophages. These cell types in turn create an immunosuppressive tumor microenvironment that prevents CD ${ }^{+} \mathrm{T}$-cell-mediated antitumor immune responses. In addition, TRAIL expressed by cancer cells or noncancer cells in the tumor microenvironment can directly kill TRAIL-R1/2-expressing immune cells, which are required for mounting an adaptive immune response, such as dendritic cells (DCs) or T cells, and thereby interfere with adaptive antitumor immunity. (B) Cancer cells have the potential to induce the expression of CD95L on different cell types of the tumor microenvironment, such as endothelial cells, MDSCs, and fibroblasts. By cross-linking CD95 on the surface of T cells, CD95L induces their demise by apoptosis, thereby facilitating tumor cell evasion from an adaptive immune attack.

Intriguingly, CD95L, arguably the best T-cell killer encoded by our genome and the physiological mediator of activation-induced T-cell death (Alderson et al. 1995; Brunner et al. 1995; Dhein et al. 1995; Ju et al. 1995), can also be expressed by various cells in the tumor microenvironment, including endothelial cells (Motz et al. 2014), MDSCs (Zhu et al. 2017), and cancer-associated fibroblasts (Lakins et al. 2018). Thus, CD95L inhibition may also act by a combination of tumor-cell-centered suppressive and immunityenabling antitumor effects (Fig. 3). 
In summary, both TRAIL and CD95L may represent the ultimate form of immune checkpoint. Rather than suppressing tumor immunity in the subtle manner of CTLA4 and PD-1/ PD-L1, they can remove question cells simply by killing them. Whether or not these different means are co-opted by a given cancer, or represent alternative ways by which particular cancers circumvent immune recognition, will determine whether TRAIL and/or CD95L inhibitors can serve as immune checkpoint blockers in their own right or whether they may (only) act in synergy with CTLA4- and/or PD-1/L1-targeting therapeutics. It will be exciting to answer

Q1 these imminent questions in cancer immunotherapy.

\section{CONCLUDING REMARKS}

From today's perspective, it may appear surprising that, following the tremendous success of inhibitors of the first death ligand, TNF, the entire pharmaceutical world did not follow their usual strategy, which is to move to the next family member and develop an inhibitor for that one. Although this appears the obvious strategy with the hindsight we have today, the fact that for the past 30 years the concept prevailed that TNF blockers worked because they blocked TNF-induced gene expression and not TNFinduced cell death, blurred the picture. However, now that it has been realized that in many cases it is indeed the inhibition of TNF-induced cell death that affords therapeutic benefit, the blurring is gone. Consequently, there is no excuse for the pharmaceutical industry not to tackle TNF's closest relatives, that is, the other death ligands, with the aim to provide therapies for patients with autoimmune or chronic inflammatory diseases, perhaps also neuroinflammatory and neurodegenerative diseases, who do not benefit from the inhibition of TNF(-induced cell death), or at least the inhibition of TNF alone. Given the newly appreciated role of DRs and their ligands in cancer-related inflammation, tumor promotion, and tumor immune suppression and evasion, the therapeutic principle of death ligand inhibition may also extend to cancer therapy.

\section{REFERENCES}

Alderson MR, Tough TW, Davis-Smith T, Braddy S, Falk B, Schooley KA, Goodwin RG, Smith CA, Ramsdell F, Lynch DH. 1995. Fas ligand mediates activation-induced cell death in human T lymphocytes. J Exp Med 181: 71-77. doi:10.1084/jem.181.1.71

Annibaldi A, Meier P. 2018. Checkpoints in TNF-induced cell death: implications in inflammation and cancer. Trends Mol Med 24: 49-65. doi:10.1016/j.molmed.2017 .11 .002

Annibaldi A, Wicky John S, Vanden Berghe T, Swatek KN, Ruan J, Liccardi G, Bianchi K, Elliott PR, Choi SM, Van Coillie S, et al. 2018. Ubiquitin-mediated regulation of RIPK1 kinase activity independent of IKK and MK2. Mol Cell 69: 566-580.e5. doi:10.1016/j.molcel.2018.01 .027

Balkwill F. 2009. Tumour necrosis factor and cancer. Nat Rev Cancer 9: 361-371. doi:10.1038/nrc2628

Balkwill FR, Mantovani A. 2012. Cancer-related inflammation: common themes and therapeutic opportunities. Semin Cancer Biol 22: 33-40. doi:10.1016/j.semcancer .2011.12.005

Barnhart BC, Legembre P, Pietras E, Bubici C, Franzoso G, Peter ME. 2004. CD95 ligand induces motility and invasiveness of apoptosis-resistant tumor cells. EMBO J 23: 3175-3185. doi:10.1038/sj.emboj.7600325

Bathon JM, Martin RW, Fleischmann RM, Tesser JR, Schiff MH, Keystone EC, Genovese MC, Wasko MC, Moreland LW, Weaver AL, et al. 2000. A comparison of etanercept and methotrexate in patients with early rheumatoid arthritis. N Engl J Med 343: 1586-1593. doi:10.1056/ NEJM200011303432201

Berger SB, Kasparcova V, Hoffman S, Swift B, Dare L, Schaeffer M, Capriotti C, Cook M, Finger J, Hughes-Earle A, et al. 2014. Cutting edge: RIP1 kinase activity is dispensable for normal development but is a key regulator of inflammation in SHARPIN-deficient mice. J Immunol 192: 5476-5480. doi:10.4049/jimmunol.1400499

Beug ST, Tang VA, LaCasse EC, Cheung HH, Beauregard CE, Brun J, Nuyens JP, Earl N, St-Jean M, Holbrook J, et al. 2014. Smac mimetics and innate immune stimuli synergize to promote tumor death. Nat Biotechnol 32: 182190. doi:10.1038/nbt.2806

Beug ST, Beauregard CE, Healy C, Sanda T, St-Jean M, Chabot J, Walker DE, Mohan A, Earl N, Lun X, et al. 2017. Smac mimetics synergize with immune checkpoint inhibitors to promote tumour immunity against glioblastoma. Nat Commun 8: 14278 . doi:10.1038/ncomms 14278

Beutler BA. 1999. The role of tumor necrosis factor in health and disease. J Rheumatol Suppl 57: 16-21.

Brennan FM, Chantry D, Jackson A, Maini R, Feldmann M. 1989. Inhibitory effect of TNF $\alpha$ antibodies on synovial cell interleukin-1 production in rheumatoid arthritis. Lancet 334: 244-247. doi:10.1016/S0140-6736(89) 90430-3

Brenner D, Blaser H, Mak TW. 2015. Regulation of tumour necrosis factor signalling: live or let die. Nat Rev Immunol 15: 362-374. doi:10.1038/nri3834

Brumatti G, Ma C, Lalaoui N, Nguyen NY, Navarro M, Tanzer MC, Richmond J, Ghisi M, Salmon JM, Silke N, et al. 2016. The caspase- 8 inhibitor emricasan combines 
with the SMAC mimetic birinapant to induce necroptosis and treat acute myeloid leukemia. Sci Transl Med 8: 339ra369. doi:10.1126/scitranslmed.aad3099

Brunner T, Mogil RJ, LaFace D, Yoo NJ, Mahboubi A, Echeverri F, Martin SJ, Force WR, Lynch DH, Ware CF, et al. 1995. Cell-autonomous Fas (CD95)/Fas-ligand interaction mediates activation-induced apoptosis in T-cell hybridomas. Nature 373: 441-444. doi:10.1038/373441a0

Carswell EA, Old LJ, Kassel RL, Green S, Fiore N, Williamson B. 1975. An endotoxin-induced serum factor that causes necrosis of tumors. Proc Natl Acad Sci 72: 3666 3670. doi:10.1073/pnas.72.9.3666

Chen L, Park SM, Tumanov AV, Hau A, Sawada K, Feig C, Turner JR, Fu YX, Romero IL, Lengyel E, et al. 2010. CD95 promotes tumour growth. Nature 465: 492-496. doi:10 $.1038 /$ nature09075

Chinnaiyan AM, O’Rourke K, Tewari M, Dixit VM. 1995. FADD, a novel death domain-containing protein, interacts with the death domain of Fas and initiates apoptosis. Cell 81: 505-512. doi:10.1016/0092-8674(95)90071-3

Chinnaiyan AM, O'Rourke K, Yu GL, Lyons RH, Garg M, Duan DR, Xing L, Gentz R, Ni J, Dixit VM. 1996. Signal transduction by DR3, a death domain-containing receptor related to TNFR-1 and CD95. Science 274: 990-992. doi:10.1126/science.274.5289.990

Cho JH, Feldman M. 2015. Heterogeneity of autoimmune diseases: pathophysiologic insights from genetics and implications for new therapies. Nat Med 21: 730-738. doi:10 $.1038 / \mathrm{nm} .3897$

Chu CQ, Field M, Feldmann M, Maini RN. 1991. Localization of tumor necrosis factor $\alpha$ in synovial tissues and at the cartilage-pannus junction in patients with rheumatoid arthritis. Arthritis Rheum 34: 1125-1132. doi:10 .1002/art.1780340908

Coley WB. 1893. The treatment of malignant tumors by repeated inoculations of erysipelas: with a report of ten original cases. 1893. Clin Orthop Relat Res 262: 3-11.

Croft M, Siegel RM. 2017. Beyond TNF: TNF superfamily cytokines as targets for the treatment of rheumatic diseases. Nat Rev Rheumatol 13: 217-233. doi:10.1038/ nrrheum.2017.22

Cuchet-Lourenco D, Eletto D, Wu C, Plagnol V, Papapietro O, Curtis J, Ceron-Gutierrez L, Bacon CM, Hackett S, Alsaleem B, et al. 2018. Biallelic RIPK1 mutations in humans cause severe immunodeficiency, arthritis, and intestinal inflammation. Science 361: 810-813. doi:10.1126/ science.aar2641

Dannappel M, Vlantis K, Kumari S, Polykratis A, Kim C, Wachsmuth L, Eftychi C, Lin J, Corona T, Hermance N, et al. 2014. RIPK1 maintains epithelial homeostasis by inhibiting apoptosis and necroptosis. Nature 513: 90-94. doi:10.1038/nature13608

Deleuran BW, Chu CQ, Field M, Brennan FM, Mitchell T, Feldmann M, Maini RN. 1992. Localization of tumor necrosis factor receptors in the synovial tissue and cartilage-pannus junction in patients with rheumatoid arthritis. Implications for local actions of tumor necrosis factor a. Arthritis Rheum 35: 1170-1178. doi:10.1002/art 1780351009

Dhein J, Walczak H, Bäumler C, Debatin KM, Krammer PH. 1995. Autocrine T-cell suicide mediated by APO-1/(Fas/ CD95). Nature 373: 438-441. doi:10.1038/373438a0
Dondelinger Y, Jouan-Lanhouet S, Divert T, Theatre E, Bertin J, Gough PJ, Giansanti P, Heck AJ, Dejardin E, Vandenabeele P, et al. 2015. NF- $\kappa B$-independent role of IKK $\alpha /$ IKK $\beta$ in preventing RIPK1 kinase-dependent apoptotic and necroptotic cell death during TNF signaling. Mol Cell 60: 63-76. doi:10.1016/j.molcel.2015.07.032

Dondelinger Y, Delanghe T, Priem D, Wynosky-Dolfi MA, Sorobetea D, Rojas-Rivera D, Giansanti P, Roelandt R, Gropengiesser J, Ruckdeschel K, et al. 2019. Serine 25 phosphorylation inhibits RIPK1 kinase-dependent cell death in models of infection and inflammation. Nat Commun 10: 1729. doi:10.1038/s41467-019-09690-0

Draber P, Kupka S, Reichert M, Draberova H, Lafont E, de Miguel D, Spilgies L, Surinova S, Taraborrelli L, Hartwig T, et al. 2015. LUBAC-recruited CYLD and A20 regulate gene activation and cell death by exerting opposing effects on linear ubiquitin in signaling complexes. Cell Rep 13: 2258-2272. doi:10.1016/j.celrep.2015.11.009

Dynek JN, Goncharov T, Dueber EC, Fedorova AV, IzraelTomasevic A, Phu L, Helgason E, Fairbrother WJ, Deshayes K, Kirkpatrick DS, et al. 2010. c-IAP1 and UbcH5 promote K11-linked polyubiquitination of RIP1 in TNF signalling. $E M B O J$ 29: 4198-4209. doi:10.1038/emboj .2010 .300

Egberts JH, Cloosters V, Noack A, Schniewind B, Thon L, Klose S, Kettler B, von Forstner C, Kneitz C, Tepel J, et al. 2008. Anti-tumor necrosis factor therapy inhibits pancreatic tumor growth and metastasis. Cancer Res 68: 14431450. doi:10.1158/0008-5472.CAN-07-5704

Elliott MJ, Maini RN, Feldmann M, Long-Fox A, Charles P, Katsikis P, Brennan FM, Walker J, Bijl H, Ghrayeb J, et al. 1993. Treatment of rheumatoid arthritis with chimeric monoclonal antibodies to tumor necrosis factor $\alpha$. Arthritis Rheum 36: 1681-1690. doi:10.1002/art.1780361206

Ermolaeva MA, Michallet MC, Papadopoulou N, Utermöhlen O, Kranidioti K, Kollias G, Tschopp J, Pasparakis M. 2008. Function of TRADD in tumor necrosis factor receptor 1 signaling and in TRIF-dependent inflammatory responses. Nat Immunol 9: 1037-1046. doi:10.1038/ni .1638

Feoktistova M, Geserick P, Kellert B, Dimitrova DP, Langlais C, Hupe M, Cain K, MacFarlane M, Häcker G, Leverkus M. 2011. cIAPs block ripoptosome formation, a RIP1/ caspase-8 containing intracellular cell death complex differentially regulated by cFLIP isoforms. Mol Cell 43: 449463. doi:10.1016/j.molcel.2011.06.011

Fritsch M, Günther SD, Schwarzer R, Albert MC, Schorn F, Werthenbach JP, Schiffmann LM, Stair N, Stocks H, Seeger JM, et al. 2019. Caspase-8 is the molecular switch for apoptosis, necroptosis and pyroptosis. Nature 575: 683687. doi:10.1038/s41586-019-1770-6

Fusco F, Pescatore A, Bal E, Ghoul A, Paciolla M, Lioi MB D'Urso M, Rabia SH, Bodemer C, Bonnefont JP, et al. 2008. Alterations of the IKBKG locus and diseases: an update and a report of 13 novel mutations. Hum Mutat 29: 595-604. doi:10.1002/humu.20739

Gerlach B, Cordier SM, Schmukle AC, Emmerich CH, Rieser E, Haas TL, Webb AI, Rickard JA, Anderton H, Wong WW, et al. 2011. Linear ubiquitination prevents inflammation and regulates immune signalling. Nature 471: 591-596. doi:10.1038/nature09816 
Gray PW, Aggarwal BB, Benton CV, Bringman TS, Henzel WJ, Jarrett JA, Leung DW, Moffat B, Ng P, Svedersky LP, et al. 1984. Cloning and expression of cDNA for human lymphotoxin, a lymphokine with tumour necrosis activity. Nature 312: 721-724. doi:10.1038/312721a0

Haas TL, Emmerich CH, Gerlach B, Schmukle AC, Cordier SM, Rieser E, Feltham R, Vince J, Warnken U, Wenger T, et al. 2009. Recruitment of the linear ubiquitin chain assembly complex stabilizes the TNF-R1 signaling complex and is required for TNF-mediated gene induction. Mol Cell 36: 831-844. doi:10.1016/j.molcel.2009.10.013

Hartwig T, Montinaro A, von Karstedt S, Sevko A, Surinova S, Chakravarthy A, Taraborrelli L, Draber P, Lafont E, Arce Vargas F, et al. 2017. The TRAIL-induced cancer secretome promotes a tumor-supportive immune microenvironment via CCR2. Mol Cell 65: 730-742.e5. doi:10 $.1016 /$ j.molcel.2017.01.021

Henry CM, Martin SJ. 2017. Caspase-8 acts in a non-enzymatic role as a scaffold for assembly of a pro-inflammatory "FADDosome" complex upon TRAIL stimulation. Mol Cell 65: 715-729.e5. doi:10.1016/j.molcel.2017.01 .022

Holler N, Tardivel A, Kovacsovics-Bankowski M, Hertig S, Gaide O, Martinon F, Tinel A, Deperthes D, Calderara S, Schulthess T, et al. 2003. Two adjacent trimeric Fas ligands are required for Fas signaling and formation of a death-inducing signaling complex. Mol Cell Biol 23: 1428-1440. doi:10.1128/MCB.23.4.1428-1440.2003

Hoogwater FJ, Nijkamp MW, Smakman N, Steller EJ, Emmink BL, Westendorp BF, Raats DA, Sprick MR, Schaefer U, Van Houdt WJ, et al. 2010. Oncogenic K-Ras turns death receptors into metastasis-promoting receptors in human and mouse colorectal cancer cells. Gastroenterology 138: 2357-2367. doi:10.1053/j.gastro.2010.02.046

Hsu H, Huang J, Shu HB, Baichwal V, Goeddel DV. 1996. TNF-dependent recruitment of the protein kinase RIP to the TNF receptor-1 signaling complex. Immunity 4: 387396. doi:10.1016/S1074-7613(00)80252-6

Ikeda T, Hirata S, Fukushima S, Matsunaga Y, Ito T, Uchino M, Nishimura Y, Senju S. 2010. Dual effects of TRAIL in suppression of autoimmunity: the inhibition of Th1 cells and the promotion of regulatory T cells. J Immunol 185: 5259-5267. doi:10.4049/jimmunol.0902797

Ikeda F, Deribe YL, Skånland SS, Stieglitz B, Grabbe C, Franz-Wachtel M, van Wijk SJ, Goswami P, Nagy V, Terzic J, et al. 2011. SHARPIN forms a linear ubiquitin ligase complex regulating NF- $\mathrm{\kappa B}$ activity and apoptosis. Nature 471: 637-641. doi:10.1038/nature09814

Ising $\mathrm{C}$, Venegas $\mathrm{C}$, Zhang $\mathrm{S}$, Scheiblich $\mathrm{H}$, Schmidt SV, Vieira-Saecker A, Schwartz S, Albasset S, McManus RM, Tejera D, et al. 2019. NLRP3 inflammasome activation drives tau pathology. Nature 575: 669-673. doi:10 .1038/s41586-019-1769-Z

Itoh N, Nagata S. 1993. A novel protein domain required for apoptosis. Mutational analysis of human Fas antigen. J Biol Chem 268: 10932-10937.

Itoh N, Yonehara S, Ishii A, Yonehara M, Mizushima S, Sameshima M, Hase A, Seto Y, Nagata S. 1991. The polypeptide encoded by the cDNA for human cell surface antigen Fas can mediate apoptosis. Cell 66: 233-243. doi:10.1016/0092-8674(91)90614-5
Jaco I, Annibaldi A, Lalaoui N, Wilson R, Tenev T, Laurien L, Kim C, Jamal K, Wicky John S, Liccardi G, et al. 2017. MK2 phosphorylates RIPK1 to prevent TNF-induced cell death. Mol Cell 66: 698-710.e5. doi:10.1016/j.molcel.2017 .05 .003

Jin Z, Li Y, Pitti R, Lawrence D, Pham VC, Lill JR, Ashkenazi A. 2009. Cullin3-based polyubiquitination and p62-dependent aggregation of caspase- 8 mediate extrinsic apoptosis signaling. Cell 137: 721-735. doi:10.1016/j.cell .2009.03.015

Ju ST, Panka DJ, Cui H, Ettinger R, El-Khatib M, Sherr DH, Stanger BZ, Marshak-Rothstein A. 1995. Fas(CD95)/FasL interactions required for programmed cell death after T-cell activation. Nature 373: 444-448. doi:10.1038/ 373444a0

Kalliolias GD, Ivashkiv LB. 2016. TNF biology, pathogenic mechanisms and emerging therapeutic strategies. Nat Rev Rheumatol 12: 49-62. doi:10.1038/nrrheum.2015.169

Kelliher MA, Grimm S, Ishida Y, Kuo F, Stanger BZ, Leder P. 1998. The death domain kinase RIP mediates the TNFinduced NF-kB signal. Immunity 8: 297-303. doi:10 .1016/S1074-7613(00)80535-X

Kleber S, Sancho-Martinez I, Wiestler B, Beisel A, Gieffers C, Hill O, Thiemann M, Mueller W, Sykora J, Kuhn A, et al. 2008. Yes and PI3K bind CD95 to signal invasion of glioblastoma. Cancer Cell 13: 235-248. doi:10.1016/j.ccr 2008.02.003

Kulbe H, Thompson R, Wilson JL, Robinson S, Hagemann T, Fatah R, Gould D, Ayhan A, Balkwill F. 2007. The inflammatory cytokine tumor necrosis factor- $\alpha$ generates an autocrine tumor-promoting network in epithelial ovarian cancer cells. Cancer Res 67: 585-592. doi:10 .1158/0008-5472.CAN-06-2941

Kumari S, Redouane Y, Lopez-Mosqueda J, Shiraishi R, Romanowska M, Lutzmayer S, Kuiper J, Martinez C, Dikic I, Pasparakis M, et al. 2014. Sharpin prevents skin inflammation by inhibiting TNFR1-induced keratinocyte apoptosis. eLife 3: e03422. doi:10.7554/eLife.03422

Lafont E, Kantari-Mimoun C, Draber P, De Miguel D, Hartwig T, Reichert M, Kupka S, Shimizu Y, Taraborrelli L, Spit M, et al. 2017. The linear ubiquitin chain assembly complex regulates TRAIL-induced gene activation and cell death. $Е M B O J$ 36: 1147-1166. doi:10.15252/embj 201695699

Lafont E, Draber P, Rieser E, Reichert M, Kupka S, de Miguel $\mathrm{D}$, Draberova $\mathrm{H}$, von Mässenhausen A, Bhamra A, Henderson S, et al. 2018. TBK1 and IKKe prevent TNFinduced cell death by RIPK1 phosphorylation. Nat Cell Biol 20: 1389-1399. doi:10.1038/s41556-018-0229-6

Lakins MA, Ghorani E, Munir H, Martins CP, Shields JD. 2018. Cancer-associated fibroblasts induce antigen-specific deletion of $\mathrm{CD} 8^{+} \mathrm{T}$ cells to protect tumour cells. Nat Commun 9: 948. doi:10.1038/s41467-018-03347-0

Lalaoui N, Hänggi K, Brumatti G, Chau D, Nguyen NY, Vasilikos L, Spilgies LM, Heckmann DA, Ma C, Ghisi M, et al. 2016. Targeting p38 or MK2 enhances the anti-leukemic activity of Smac-mimetics. Cancer Cell 29: 145-158. doi:10.1016/j.ccell.2016.01.006

Lehnert C, Weiswange M, Jeremias I, Bayer C, Grunert M, Debatin KM, Strauss G. 2014. TRAIL-receptor costimulation inhibits proximal TCR signaling and suppresses 
human T cell activation and proliferation. J Immunol 193: 4021-4031. doi:10.4049/jimmunol.1303242

Lenercept Multiple Sclerosis Study Group. 1999. TNF neutralization in MS: results of a randomized, placebocontrolled multicenter study. The Lenercept Multiple Sclerosis Study Group and The University of British Columbia MS/MRI Analysis Group. Neurology 53: 457-465. doi:10.1212/WNL.53.3.457

Leverkus M, Walczak H, McLellan A, Fries HW, Terbeck G, Bröcker EB, Kämpgen E. 2000. Maturation of dendritic cells leads to up-regulation of cellular FLICE-inhibitory protein and concomitant down-regulation of death ligand-mediated apoptosis. Blood 96: 2628-2631. doi:10 .1182/blood.V96.7.2628

Loetscher H, Pan YC, Lahm HW, Gentz R, Brockhaus M, Tabuchi H, Lesslauer W. 1990. Molecular cloning and expression of the human $55 \mathrm{kd}$ tumor necrosis factor receptor. Cell 61: 351-359. doi:10.1016/0092-8674(90) 90815-V

Lopetuso LR, Gerardi V, Papa V, Scaldaferri F, Rapaccini GL, Gasbarrini A, Papa A. 2017. Can we predict the efficacy of anti-TNF- $\alpha$ agents? Int J Mol Sci 18: 1973. doi:10.3390/ ijms 18091973

Lovell DJ, Giannini EH, Reiff A, Cawkwell GD, Silverman ED, Nocton JJ, Stein LD, Gedalia A, Ilowite NT, Wallace CA, et al. 2000. Etanercept in children with polyarticular juvenile rheumatoid arthritis. N Engl J Med 342: 763-769. doi:10.1056/NEJM200003163421103

Mantovani A, Allavena P, Sica A, Balkwill F. 2008. Cancerrelated inflammation. Nature 454: 436-444. doi:10.1038/ nature 07205

Marmenout A, Fransen L, Tavernier J, Van der Heyden J, Tizard R, Kawashima E, Shaw A, Johnson MJ, Semon D, Muller R, et al. 1985. Molecular cloning and expression of human tumor necrosis factor and comparison with mouse tumor necrosis factor. Eur J Biochem 152: 515 522. doi:10.1111/j.1432-1033.1985.tb09226.x

Marsters SA, Sheridan JP, Donahue CJ, Pitti RM, Gray CL, Goddard AD, Bauer KD, Ashkenazi A. 1996. Apo-3, a new member of the tumor necrosis factor receptor family, contains a death domain and activates apoptosis and NFкB. Curr Biol 6: 1669-1676. doi:10.1016/S0960-9822(02) 70791-4

Medler J, Wajant H. 2019. Tumor necrosis factor receptor-2 (TNFR2): an overview of an emerging drug target. Expert Opin Ther Targets 23: 295-307. doi:10.1080/14728222 .2019.1586886

Micheau O, Tschopp J. 2003. Induction of TNF receptor I-mediated apoptosis via two sequential signaling complexes. Cell 114: 181-190. doi:10.1016/S0092-8674(03) 00521-X

Monaco C, Nanchahal J, Taylor P, Feldmann M. 2015. AntiTNF therapy: past, present and future. Int Immunol 27: 55-62. doi:10.1093/intimm/dxu102

Moore RJ, Owens DM, Stamp G, Arnott C, Burke F, East N, Holdsworth H, Turner L, Rollins B, Pasparakis M, et al. 1999. Mice deficient in tumor necrosis factor- $\alpha$ are resistant to skin carcinogenesis. Nat Med 5: 828-831. doi:10 $.1038 / 10552$

Moreland LW, Schiff MH, Baumgartner SW, Tindall EA, Fleischmann RM, Bulpitt KJ, Weaver AL, Keystone EC, Furst DE, Mease PJ, et al. 1999. Etanercept therapy in rheumatoid arthritis: a randomized, controlled trial. Ann Intern Med 130: 478-486. doi:10.7326/0003-4819130-6-199903160-00004

Motz GT, Santoro SP, Wang LP, Garrabrant T, Lastra RR, Hagemann IS, Lal P, Feldman MD, Benencia F, Coukos G. 2014. Tumor endothelium FasL establishes a selective immune barrier promoting tolerance in tumors. Nat Med 20: 607-615. doi:10.1038/nm.3541

Nauts HC, Swift WE, Coley BL. 1946. The treatment of malignant tumors by bacterial toxins as developed by the late William B. Coley, M.D., reviewed in the light of modern research. Cancer Res 6: 205-216.

Neuwirth MG, Song Y, Sinnamon AJ, Fraker DL, Zager JS, Karakousis GC. 2017. Isolated limb perfusion and infusion for extremity soft tissue sarcoma: a contemporary systematic review and meta-analysis. Ann Surg Oncol 24: 3803-3810. doi:10.1245/s10434-017-6109-7

Newton K, Dugger DL, Maltzman A, Greve JM, Hedehus M, Martin-McNulty B, Carano RA, Cao TC, van Bruggen N, Bernstein L, et al. 2016. RIPK3 deficiency or catalytically inactive RIPK1 provides greater benefit than MLKL deficiency in mouse models of inflammation and tissue injury. Cell Death Differ 23: 1565-1576. doi:10.1038/cdd.2016 .46

Newton K, Wickliffe KE, Maltzman A, Dugger DL, Reja R, Zhang Y, Roose-Girma M, Modrusan Z, Sagolla MS, Webster JD, et al. 2019. Activity of caspase-8 determines plasticity between cell death pathways. Nature 575: 679682. doi:10.1038/s41586-019-1752-8

Oda H, Beck DB, Kuehn HS, Sampaio Moura N, Hoffmann P, Ibarra M, Stoddard J, Tsai WL, Gutierrez-Cruz G, Gadina M, et al. 2019. Second case of HOIP deficiency expands clinical features and defines inflammatory transcriptome regulated by LUBAC. Front Immunol 10: 479. doi:10.3389/fimmu.2019.00479

Oehm A, Behrmann I, Falk W, Pawlita M, Maier G, Klas C, Li-Weber M, Richards S, Dhein J, Trauth BC, et al. 1992. Purification and molecular cloning of the APO- 1 cell surface antigen, a member of the tumor necrosis factor/nerve growth factor receptor superfamily. Sequence identity with the Fas antigen. J Biol Chem 267: 10709-10715.

Ogasawara J, Watanabe-Fukunaga R, Adachi M, Matsuzawa A, Kasugai T, Kitamura Y, Itoh N, Suda T, Nagata S. 1993. Lethal effect of the anti-Fas antibody in mice. Nature 364: 806-809. doi:10.1038/364806a0

Ori D, Kato H, Sanjo H, Tartey S, Mino T, Akira S, Takeuchi O. 2013. Essential roles of K63-linked polyubiquitinbinding proteins $\mathrm{TAB} 2$ and $\mathrm{TAB} 3$ in $\mathrm{B}$ cell activation via MAPKs. J Immunol 190: 4037-4045. doi:10.4049/jim munol.1300173

Owen-Schaub LB, Meterissian S, Ford RJ. 1993. Fas/APO-1 expression and function on malignant cells of hematologic and nonhematologic origin. J Immunother Emphasis Tumor Immunol 14: 234-241. doi:10.1097/00002371199310000-00011

Pan G, Ni J, Wei YF, Yu G, Gentz R, Dixit VM. 1997a. An antagonist decoy receptor and a death domain-containing receptor for TRAIL. Science 277: 815-818. doi:10 $.1126 /$ science.277.5327.815

Pan G, O’Rourke K, Chinnaiyan AM, Gentz R, Ebner R, Ni J, Dixit VM. 1997b. The receptor for the cytotoxic ligand 
TRAIL. Science 276: 111-113. doi:10.1126/science.276 .5309 .111

Pasparakis M, Vandenabeele P. 2015. Necroptosis and its role in inflammation. Nature 517: 311-320. doi:10 1038 /nature14191

Patel S, Webster JD, Varfolomeev E, Kwon YC, Cheng JH, Zhang J, Dugger DL, Wickliffe KE, Maltzman A, SujathaBhaskar S, et al. 2020. RIP1 inhibition blocks inflammatory diseases but not tumor growth or metastases. Cell Death Differ 27: 161-175. doi: 10.1038/s41418-0190347-0.

Peltzer N, Walczak H. 2019. Cell death and inflammation-a vital but dangerous liaison. Trends Immunol 40: 387-402. doi:10.1016/j.it.2019.03.006

Peltzer N, Darding M, Walczak H. 2016. Holding RIPK1 on the ubiquitin leash in TNFR1 signaling. Trends Cell Biol 26: 445-461. doi:10.1016/j.tcb.2016.01.006

Peltzer N, Darding M, Montinaro A, Draber P, Draberova H, Kupka S, Rieser E, Fisher A, Hutchinson C, Taraborrelli L, et al. 2018. LUBAC is essential for embryogenesis by preventing cell death and enabling haematopoiesis. Nature 557: 112-117. doi:10.1038/s41586-018-0064-8

Pennica D, Nedwin GE, Hayflick JS, Seeburg PH, Derynck R, Palladino MA, Kohr WJ, Aggarwal BB, Goeddel DV. 1984. Human tumour necrosis factor: precursor structure, expression and homology to lymphotoxin. Nature 312: 724-729. doi:10.1038/312724a0

Pillai MR, Collison LW, Wang X, Finkelstein D, Rehg JE, Boyd K, Szymczak-Workman AL, Doggett T, Griffith TS, Ferguson TA, et al. 2011. The plasticity of regulatory T cell function. J Immunol 187: 4987-4997. doi:10.4049/ jimmunol.1102173

Pitti RM, Marsters SA, Ruppert S, Donahue CJ, Moore A, Ashkenazi A. 1996. Induction of apoptosis by Apo-2 ligand, a new member of the tumor necrosis factor cytokine family. J Biol Chem 271: 12687-12690. doi:10.1074/jbc .271.22.12687

Rahighi S, Ikeda F, Kawasaki M, Akutsu M, Suzuki N, Kato R, Kensche T, Uejima T, Bloor S, Komander D, et al. 2009. Specific recognition of linear ubiquitin chains by NEMO is important for NF- $\mathrm{KB}$ activation. Cell 136: 1098-1109. doi:10.1016/j.cell.2009.03.007

Richard AC, Ferdinand JR, Meylan F, Hayes ET, Gabay O, Siegel RM. 2015. The TNF-family cytokine TL1A: from lymphocyte costimulator to disease co-conspirator. J Leukoc Biol 98: 333-345. doi:10.1189/jlb.3RI0315-095R

Rickard JA, Anderton H, Etemadi N, Nachbur U, Darding M, Peltzer N, Lalaoui N, Lawlor KE, Vanyai H, Hall C, et al. 2014. TNFR1-dependent cell death drives inflammation in Sharpin-deficient mice. eLife 3: e03464. doi:10 .7554/eLife.03464

Robaye B, Mosselmans R, Fiers W, Dumont JE, Galand P. 1991. Tumor necrosis factor induces apoptosis (programmed cell death) in normal endothelial cells in vitro. Am J Pathol 138: 447-453.

Roberts AI, Devadas S, Zhang X, Zhang L, Keegan A, Greeneltch K, Solomon J, Wei L, Das J, Sun E, et al. 2003. The role of activation-induced cell death in the differentiation of T-helper-cell subsets. Immunol Res 28: 285-293. doi:10 .1385/IR:28:3:285

Rothe M, Pan MG, Henzel WJ, Ayres TM, Goeddel DV. 1995. The TNFR2-TRAF signaling complex contains two novel proteins related to baculoviral inhibitor of apoptosis proteins. Cell 83: 1243-1252. doi:10.1016/00928674(95)90149-3

Schall TJ, Lewis M, Koller KJ, Lee A, Rice GC, Wong GH, Gatanaga T, Granger GA, Lentz R, Raab H, et al. 1990. Molecular cloning and expression of a receptor for human tumor necrosis factor. Cell 61: 361-370. doi:10.1016/ 0092-8674(90)90816-W

Screaton GR, Mongkolsapaya J, Xu XN, Cowper AE, McMichael AJ, Bell JI. 1997a. TRICK2, a new alternatively spliced receptor that transduces the cytotoxic signal from TRAIL. Curr Biol 7: 693-696. doi:10.1016/S09609822(06)00297-1

Screaton GR, Xu XN, Olsen AL, Cowper AE, Tan R, McMichael AJ, Bell JI. 1997b. LARD: a new lymphoid-specific death domain containing receptor regulated by alternative pre-mRNA splicing. Proc Natl Acad Sci 94: 46154619. doi:10.1073/pnas.94.9.4615

Seymour RE, Hasham MG, Cox GA, Shultz LD, Hogenesch H, Roopenian DC, Sundberg JP. 2007. Spontaneous mutations in the mouse Sharpin gene result in multiorgan inflammation, immune system dysregulation and dermatitis. Genes Immun 8: 416-421. doi:10.1038/sj.gene .6364403

Sheridan JP, Marsters SA, Pitti RM, Gurney A, Skubatch M, Baldwin D, Ramakrishnan L, Gray CL, Baker K, Wood WI, et al. 1997. Control of TRAIL-induced apoptosis by a family of signaling and decoy receptors. Science 277: 818821. doi:10.1126/science.277.5327.818

Shirley S, Morizot A, Micheau O. 2011. Regulating TRAIL receptor-induced cell death at the membrane: a deadly discussion. Recent Pat Anticancer Drug Discov 6: 311323. doi:10.2174/157489211796957757

Suganuma M, Okabe S, Marino MW, Sakai A, Sueoka E, Fujiki H. 1999. Essential role of tumor necrosis factor $\alpha$ (TNF- $\alpha$ ) in tumor promotion as revealed by TNF- $\alpha$-deficient mice. Cancer Res 59: 4516-4518.

Taraborrelli L, Peltzer N, Montinaro A, Kupka S, Rieser E, Hartwig T, Sarr A, Darding M, Draber P, Haas TL, et al. 2018. LUBAC prevents lethal dermatitis by inhibiting cell death induced by TNF, TRAIL and CD95L. Nat Commun 9: 3910. doi:10.1038/s41467-018-06155-8

Tenev T, Bianchi K, Darding M, Broemer M, Langlais C, Wallberg F, Zachariou A, Lopez J, MacFarlane M, Cain $\mathrm{K}$, et al. 2011. The ripoptosome, a signaling platform that assembles in response to genotoxic stress and loss of IAPs. Mol Cell 43: 432-448. doi:10.1016/j.molcel.2011.06.006

Ting AT, Bertrand MJ. 2016. More to life than NF- $\kappa B$ in TNFR1 signaling. Trends Immunol 37: 535-545. doi:10 $.1016 /$ j.it.2016.06.002

Tracey KJ, Lowry SF, Cerami A. 1988. Cachetin/TNF- $\alpha$ in septic shock and septic adult respiratory distress syndrome. Am Rev Respir Dis 138: 1377-1379. doi:10.1164/ ajrccm/138.6.1377

Trauth BC, Klas C, Peters AM, Matzku S, Moller P, Falk W, Debatin KM, Krammer PH. 1989. Monoclonal antibodymediated tumor regression by induction of apoptosis. Science 245: 301-305. doi:10.1126/science.2787530

Trauzold A, Siegmund D, Schniewind B, Sipos B, Egberts J, Zorenkov D, Emme D, Röder C, Kalthoff H, Wajant H. 2006. TRAIL promotes metastasis of human pancreatic 
ductal adenocarcinoma. Oncogene 25: 7434-7439. doi:10 $.1038 /$ sj.onc. 1209719

Valley CC, Lewis AK, Mudaliar DJ, Perlmutter JD, Braun AR, Karim CB, Thomas DD, Brody JR, Sachs JN. 2012 Tumor necrosis factor-related apoptosis-inducing ligand (TRAIL) induces death receptor 5 networks that are highly organized. J Biol Chem 287: 21265-21278. doi:10.1074/ jbc.M111.306480

Vandenabeele P, Vanden Berghe T, Festjens N. 2006. Caspase inhibitors promote alternative cell death pathways. Sci STKE 2006: pe44. doi:10.1126/stke.3582006pe44

Vanden Berghe T, Denecker G, Brouckaert G, Vadimovisch Krysko D, D’Herde K, Vandenabeele P. 2004. More than one way to die: methods to determine TNF-induced apoptosis and necrosis. Methods Mol Med 98: 101-126.

Vlantis K, Wullaert A, Polykratis A, Kondylis V, Dannappel M, Schwarzer R, Welz P, Corona T, Walczak H, Weih F, et al. 2016. NEMO prevents RIP kinase 1-mediated epithelial cell death and chronic intestinal inflammation by $\mathrm{NF}-\kappa \mathrm{B}$-dependent and -independent functions. Immunity 44: 553-567. doi:10.1016/j.immuni.2016.02.020

von Karstedt S, Conti A, Nobis M, Montinaro A, Hartwig T, Lemke J, Legler K, Annewanter F, Campbell AD, Taraborrelli L, et al. 2015. Cancer cell-autonomous TRAIL-R signaling promotes KRAS-driven cancer progression, invasion, and metastasis. Cancer Cell 27: 561-573. doi:10 .1016/j.ccell.2015.02.014

von Karstedt S, Montinaro A, Walczak H. 2017. Exploring the TRAILs less travelled: TRAIL in cancer biology and therapy. Nat Rev Cancer 17: 352-366. doi:10.1038/nrc .2017 .28

Vredevoogd DW, Kuilman T, Ligtenberg MA, Boshuizen J, Stecker KE, de Bruijn B, Krijgsman O, Huang X, Kenski JCN, Lacroix R, et al. 2019. Augmenting immunotherapy impact by lowering tumor TNF cytotoxicity threshold. Cell 178: 585-599.e15. doi:10.1016/j.cell.2019.06.014

Wajant H, Siegmund D. 2019. TNFR1 and TNFR2 in the control of the life and death balance of macrophages. Front Cell Dev Biol 7: 91. doi:10.3389/fcell.2019.00091

Walczak H. 2013. Death receptor-ligand systems in cancer, cell death, and inflammation. Cold Spring Harb Perspect Biol 5: a008698. doi:10.1101/cshperspect.a008698

Walczak H, Degli-Esposti MA, Johnson RS, Smolak PJ, Waugh JY, Boiani N, Timour MS, Gerhart MJ, Schooley KA, Smith CA, et al. 1997. TRAIL-R2: a novel apoptosismediating receptor for TRAIL. EMBO J 16: 5386-5397. doi:10.1093/emboj/16.17.5386

Wang L, Du F, Wang X. 2008. TNF- $\alpha$ induces two distinct caspase- 8 activation pathways. Cell 133: 693-703. doi:10 .1016/j.cell.2008.03.036

Watanabe-Fukunaga R, Brannan CI, Copeland NG, Jenkins NA, Nagata S. 1992. Lymphoproliferation disorder in mice explained by defects in Fas antigen that mediates apoptosis. Nature 356: 314-317. doi:10.1038/356314a0

Weinblatt ME, Kremer JM, Bankhurst AD, Bulpitt KJ, Fleischmann RM, Fox RI, Jackson CG, Lange M, Burge DJ. 1999. A trial of etanercept, a recombinant tumor ne- crosis factor receptor:Fc fusion protein, in patients with rheumatoid arthritis receiving methotrexate. $N$ Engl J Med 340: 253-259. doi:10.1056/NEJM199901283400401

Welz PS, Wullaert A, Vlantis K, Kondylis V, FernándezMajada V, Ermolaeva M, Kirsch P, Sterner-Kock A, van Loo G, Pasparakis M. 2011. FADD prevents RIP3-mediated epithelial cell necrosis and chronic intestinal inflammation. Nature 477: 330-334. doi:10.1038/nature10273

Wick W, Fricke H, Junge K, Kobyakov G, Martens T, Heese O, Wiestler B, Schliesser MG, von Deimling A, Pichler J, et al. 2014. A phase II, randomized, study of weekly APG101+reirradiation versus reirradiation in progressive glioblastoma. Clin Cancer Res 20: 6304-6313. doi:10 .1158/1078-0432.CCR-14-0951-T

Wiley SR, Schooley K, Smolak PJ, Din WS, Huang CP, Nicholl JK, Sutherland GR, Smith TD, Rauch C, Smith CA, et al. 1995. Identification and characterization of a new member of the TNF family that induces apoptosis. Immunity 3: 673-682. doi:10.1016/1074-7613(95)90057-8

Wong WW, Gentle IE, Nachbur U, Anderton H, Vaux DL, Silke J. 2010. RIPK1 is not essential for TNFR1-induced activation of NF-кB. Cell Death Differ 17: 482-487. doi:10 $.1038 / \mathrm{cdd} .2009 .178$

Wu GS, Burns TF, McDonald ER III, Jiang W, Meng R, Krantz ID, Kao G, Gan DD, Zhou JY, Muschel R, et al. 1997. KILLER/DR5 is a DNA damage-inducible p53-regulated death receptor gene. Nat Genet 17: 141-143. doi:10 $.1038 /$ ng1097-141

Yonehara S, Ishii A, Yonehara M. 1989. A cell-killing monoclonal antibody (anti-Fas) to a cell surface antigen codownregulated with the receptor of tumor necrosis factor. J Exp Med 169: 1747-1756. doi:10.1084/jem.169.5.1747

Zhang XR, Zhang LY, Devadas S, Li L, Keegan AD, Shi YF. 2003. Reciprocal expression of TRAIL and CD95L in Th1 and Th2 cells: role of apoptosis in T helper subset differentiation. Cell Death Differ 10: 203-210. doi:10.1038/sj .cdd. 4401138

Zhang DW, Shao J, Lin J, Zhang N, Lu BJ, Lin SC, Dong MQ, Han J. 2009. RIP3, an energy metabolism regulator that switches TNF-induced cell death from apoptosis to necrosis. Science 325: 332-336. doi:10.1126/science .1172308

Zhu J, de Tenbossche CGP, Cané S, Colau D, van Baren N, Lurquin C, Schmitt-Verhulst AM, Liljeström P, Uyttenhove C, Van den Eynde BJ. 2017. Resistance to cancer immunotherapy mediated by apoptosis of tumor-infiltrating lymphocytes. Nat Commun 8: 1404. doi:10.1038/ s41467-017-00784-1

Zinngrebe J, Montinaro A, Peltzer N, Walczak H. 2014. Ubiquitin in the immune system. EMBO Rep 15: 28-45. doi:10.1002/embr.201338025

Zins K, Abraham D, Sioud M, Aharinejad S. 2007. Colon cancer cell-derived tumor necrosis factor- $\alpha$ mediates the tumor growth-promoting response in macrophages by up-regulating the colony-stimulating factor-1 pathway. Cancer Res 67: 1038-1045. doi:10.1158/0008-5472 .CAN-06-2295 


\section{PIBCSDa036384}

Queries

Alessandro Annibaldi, and Henning Walczak

Q1 Please confirm that "imminent" is meant.

Q2 Reference entry for "Kelliher et al. 1998" was updated to match details for this article record; please confirm accuracy of updated entry. 